\title{
Pengembangan Model Permainan Sepak Takraw sebagai Pembelajaran Pendidikan Jasmani bagi Anak SD Kelas Atas
}

\author{
Mas Setiananda Artyhadewa \\ SD Negeri Minomartani 6. Perumnas Minomartani, Jalan Kakap XI Ngaglik Sleman, Indonesia \\ Email: lavecchia09@gmail.com \\ Received: 31 January 2017; Revised:18 April 2017; Accepted: 21 April 2017
}

\begin{abstract}
Abstrak
Penelitian ini bertujuan untuk mengembangkan model permainan sepak takraw sebagai pembelajaran pendidikan jasmani bagi anak sekolah dasar kelas atas. Model permainan sepak takraw yang dikembangkan diharapkan dapat digunakan oleh guru penjasorkes sekolah dasar sebagai bentuk pembelajaran permainan bola kecil khususnya sepak takraw secara baik dan efektif pada anak kelas atas. Penelitian ini melalui sembilan tahapan dengan mengadaptasi penelitian dan pengembangan pendidikan model Gall, Gall, dan Borg. Hasil penelitian berupa pengembangan model permainan sepak takraw terdiri atas 20 jenis permainan yang dikelompokkan menjadi 5 kategori berdasarkan teknik dasar bermain yaitu sepakan, bertahan, servis, smash, dan game. Model permainan tersebut: (1) berdasarkan teknik sepakan: permainan bola apung, permainan bola jinak, permainan bola bumerang, permainan bolalik, dan permainan bolan; (2) berdasarkan teknik bertahan: permainan ombak bola, permainan bolarus, permainan bosi, permainan bolabola, dan permainan bona; (3) berdasarkan teknik servis: permainan bontung, permainan bolatong, permainan perang bola, permainan bolvis, dan permainan bovispo; (4) berdasarkan teknik smash: permainan bomes; dan (5) berdasarkan game: permainan mangdul, permainan bolnet, permainan bolnetri, dan permainan bola vokra. Model disusun dalam buku panduan berjudul "Panduan Bermain Sepak Takraw: Pembelajaran Pendidikan Jasmani bagi Anak Sekolah Dasar Kelas Atas" dan DVD pengembangan model permainan sepak takraw.
\end{abstract}

Kata Kunci: model, permainan sepak takraw, pendidikan jasmani, sekolah dasar

\section{Developing Sepak Takraw Game Models as a Physical Education Learning for the Upper Class Students of Elementary School}

\begin{abstract}
The research aims at developing models of sepak takraw game in physical education teaching for upper class students of elementary school. The model of sepak takraw game which is developed can be used by the elementary teacher in teaching small ball game especially sepak takraw for upper class students effectively. This study was a research and development conducted in nine steps by adapting educational research and development according to Gall, Gall, \& Borg's model. The result of the research is sepak takraw game models consists of 20 types of games that are grouped into five categories based on the basic playing techniques namely: kicking, defense, service, smash, and games. The game models are: (1) based on kicking techniques: bola apung game, bola jinak game, bola bumerang game, bolalik game, and bolan game; (2) based on defense techniques: ombak bola game, bolarus game, bosi game, bolabola game, and bona game; (3) based on service techniques: bontung game, bolatong game, perang bola game, bolvis game, and bovispo game; (4) based on the smash techniques: bomes game; and (5) based on the game: mangdul game, bolnet game, bolnetri game, and bola vokra game. The model developed is in the form of a guidance book entitled "Panduan Bermain Sepak Takraw: Pembelajaran Pendidikan Jasmani bagi Anak Sekolah Dasar Kelas Atas" and DVD entitled developing sepak takraw game model
\end{abstract}

Keywords: model, sepak takraw game, physical education, elementary school

How to Cite: Artyhadewa, M. (2017). Pengembangan model permainan sepak takraw sebagai pembelajaran pendidikan jasmani bagi anak SD kelas atas. Jurnal Keolahragaan, 5(1), 50-62. doi:http://dx.doi.org/10.21831/jk.v5i1.12804

Permalink/DOI: http://dx.doi.org/10.21831/jk.v5i1.12804 


\section{PENDAHULUAN}

Pendidikan jasmani, olahraga, dan kesehatan (penjasorkes) pada dasarnya merupakan bagian integral dari sistem pendidikan secara keseluruhan, bertujuan untuk mengembangkan aspek kesehatan, kebugaran jasmani, keterampilan berpikir kritis, stabilitas emosional, keterampilan sosial, penalaran, dan tindakan moral melalui aktivitas jasmani dan olahraga. Penjasorkes diselenggarakan di semua jenjang pendidikan mulai tingkat dasar, menengah, bahkan jenjang pendidikan tinggi. Penjasorkes di sekolah dasar meliputi aspek permainan dan olahraga, aktivitas pengembangan, aktivitas senam, aktivitas ritmik, aktivitas akuatik, pendidikan luar kelas dan kesehatan. Cabang olahraga sepak takraw merupakan salah satu aspek dari permainan bola kecil yang bisa diajarkan pada anak kelas atas sekolah dasar. Siswa diharapkan dapat memraktikkan permainan sepak takraw dengan peraturan yang dimodifikasi.

Permainan sepak takraw masih menjadi olahraga pilihan di dalam kurikulum penjasorkes sekolah dasar sehingga sangat jarang diajarkan. Pada Kurikulum Tingkat Satuan Pendidikan (KTSP), permainan sepak takraw secara eksplisit tidak tercantum dalam kurikulum pendidikan jasmani tingkat sekolah dasar. Materi permainan dan olahraga yang secara eksplisit disebutkan sebagai berikut (BSNP, 2009, p. 2). "Permainan dan olahraga meliputi: olahraga tradisional, permainan, eksplorasi gerak, keterampilan lokomotor, nonlokomotor, dan manipulatif, atletik, kasti, rounders, kippers, softball, baseball, bola tangan, sepak bola, bola voli, bola basket, tenis meja, tenis, bulu tangkis, dan beladiri serta aktivitas lainnya".

Permainan sepak takraw sangat baik untuk diajarkan dan dikembangkan di sekolah dasar. Permainan sepak takraw merupakan permainan yang menyerupai permainan bulu tangkis dan bola voli. Dalam permainan sepak takraw bola dikembalikan ke lapangan lawan menggunakan kaki, kepala, dan badan (Ali, Hanif, \& Jamalong, 2003, p. 51). Permainan sepak takraw menuntut para pemain memiliki keterampilan gerak manipulatif yang baik, kondisi fisik yang prima, kecepatan membuat keputusan dalam bergerak, dan kestabilan emosi (Yusup, Prawirasaputra, Sudrajat, \& Usli, 2001, pp. 20-21). Oleh karena itu, permainan sepak takraw sangat cocok untuk mencapai tujuan pembelajaran pendidikan jasmani di sekolah yaitu meningkatkan pertumbuhan baik secara fisik maupun psikis. Permainan sepak takraw merupakan permainan net games yang dilakukan secara beregu. Permainan sepak takraw tidak memerlukan lapangan yang luas serta peralatan yang rumit. Lapangan yang digunakan hanya seluas 13,4 meter x 6,1 meter dan menggunakan bola berbahan dasar rotan atau fiber. Penggunaan lapangan yang tidak terlalu luas dalam permainan sepak takraw sangat tepat untuk menunjang pembelajaran dan materi permainan yang diajarkan di sekolah dasar. Sekolah dasar rata-rata hanya memiliki lapangan olahraga yang sempit.

Permainan sepak takraw adalah permainan sederhana yang membutuhkan keterampilan lebih. Keterampilan lebih tersebut akan didapat jika seseorang mengetahui dan mau melakukan permainan sepak takraw. Permainan sepak takraw merupakan permainan yang menarik untuk diajarkan di sekolah dasar. Hal ini dikarenakan permainan sepak takraw menggunakan bola yang terbuat dari rotan yang dimainkan dengan seluruh badan kecuali tangan dan dilakukan dengan gerakan yang atraktif seperti gerakan salto ketika smash atau ketika melakukan penyelamatan bola. Gerakan-gerakan tersebut akan dapat memacu dan memberikan tantangan kepada para siswa di sekolah dasar untuk bermain sepak takraw.

Kenyataan di lapangan, permainan sepak takraw sangat jarang dan bahkan belum dikenalkan atau diajarkan oleh guru penjasorkes kepada siswa. Hal ini dibuktikan dari hasil observasi dan wawancara peneliti ke beberapa sekolah dasar yaitu SD Negeri Minomartani 1 Ngaglik, SD Negeri Minomartani 6 Ngaglik, SD Negeri Dayuharjo Ngaglik, dan SD Negeri Brengosan 2 Ngaglik. Berdasarkan hasil observasi dan wawancara terungkap ada empat permasalahan mengenai pembelajaran sepak takraw di sekolah dasar kelas atas sebagai berikut.

Pertama, guru penjasorkes lebih sering mengajarkan permainan kasti dan bulu tangkis sebagai pembelajaran permainan bola kecil kepada anak kelas atas. Permainan kasti dan bulu tangkis dianggap mudah diajarkan guru penjasorkes dan dilakukan oleh anak, sehingga materi permainan bola kecil yang diajarkan dari semester pertama dan kedua hanya mengalami pengulangan permainan. Permainan bola kecil lain jarang diajarkan.

Kedua, sekolah belum memiliki sarana dan prasarana untuk bermain sepak takraw. Sekolah yang diobservasi hanya memiliki lapangan olahraga yaitu lapangan sepak bola, 
lapangan bulu tangkis, lapangan bola voli, dan sepetak tanah lapang yang tidak terlalu luas. Sekolah tidak memiliki peralatan olahraga yang dibutuhkan untuk bermain sepak takraw seperti bola takraw dan net sepak takraw. Peralatan yang dimiliki sekolah yaitu bola kasti, bola tenis, bola sepak, bola basket, dan bola voli. Sementara net yang tersedia di sekolah adalah net bola voli dan bulu tangkis. Karena tidak ada sarana dan prasarana untuk bermain sepak takraw, pembelajaran permainan bola kecil khususnya sepak takraw tidak diajarkan kepada anak kelas atas.

Ketiga, sebagian guru penjasorkes masih memiliki persepsi bahwa permainan sepak takraw merupakan permainan yang sulit untuk dilakukan dan diajarkan. Sebagian guru penjasorkes menganggap teknik atau keterampilan untuk menguasai bola takraw sangat susah. Dari persepsi dan anggapan tersebut dapat disimpulkan sebagian guru penjasorkes belum bisa melakukan permainan sepak takraw sehingga tidak percaya diri untuk mengajarkan permainan sepak takraw kepada anak. Guru penjasorkes takut salah memberikan contoh yang benar dalam bermain sepak takraw kepada anak.

Keempat, referensi buku permainan sepak takraw menjadi kendala kurangnya pengetahuan guru penjasorkes akan permainan sepak takraw. Para guru penjasorkes tidak memiliki buku tentang permainan sepak takraw. Referensi buku yang dimiliki guru penjasorkes sebagian besar mengandalkan buku paket dan hanya beracu kepada kurikulum penjasorkes.

Permasalahan dan keterbatasan tersebut mengakibatkan kecil kemungkinan guru penjasorkes mengajarkan permainan sepak takraw di sekolah dasar. Jika pembelajaran permainan sepak takraw dapat dilaksanakan akan sangat bermanfaat bagi anak. Melihat gambaran yang ada, bentuk aktivitas permainan sepak takraw sebaiknya dikembangkan agar kebutuhan akan gerak yang nantinya menunjang proses pertumbuhan dan perkembangan anak dapat terpenuhi dengan baik.

Materi permainan sepak takraw seharusnya diajarkan sebagai sarana dalam proses pendidikan yang disesuaikan dengan tumbuh kembang anak usia sekolah dasar kelas atas. Hal ini sesuai dengan Kurikulum Tingkat Satuan Pendidikan (KTSP) yang termuat dalam Standar Kompetensi 1. Mempraktekkan gerak dasar ke dalam permainan sederhana dan olahraga serta nilai-nilai yang terkandung di dalamnya dan Kompetensi Dasar 1.1 Memraktikkan gerak dasar dalam permainan bola kecil sederhana dengan peraturan yang dimodifikasi, serta nilai kerja sama tim, sportivitas, dan kejujuran.

Selain itu, materi permainan sepak takraw yang diajarkan kepada anak sekolah dasar dapat dijadikan sebagai pembinaan multilateral anak. Pembinaan multilateral anak meliputi pengembangan keterampilan gerak, pengembangan kemampuan fisik, dan pengembangan mental sosial (Lumintuarso, 2013, pp. 8-9). Permainan sepak takraw yang diajarkan kepada anak sekolah dasar diharapkan dapat memberikan pengembangan keterampilan gerak khususnya gerak dasar bermain sepak takraw, mengembangkan kebugaran jasmani anak, dan mengembangkan mental sosial anak ketika bermain sepak takraw.

Materi permainan sepak takraw yang diajarkan tidak menyulitkan dan memberatkan anak, karena anak usia sekolah dasar masih berada pada tahapan anak untuk bermain. Melalui bermain yang dirasakan anak adalah kesenangan dan kegembiraan tanpa memikirkan hasil akhir. Dengan bermain, secara tidak langsung anak akan mengenal karakteristik permainan yang diajarkan serta dapat berinteraksi secara baik dengan teman sepermainannya. Interaksi tersebut akan memotivasi anak untuk bergerak secara aktif sehingga aspek psikomotor, afektif, dan kognitif anak juga ikut berkembang.

Untuk mengenalkan dan mengembangkan permainan sepak takraw melalui pembelajaran di sekolah dasar, perlu membuat pengembangan dengan memodifikasi permainan sesuai dengan tingkat pertumbuhan dan perkembangan anak sekolah dasar. Pengembangan model permainan sepak takraw dilakukan dengan pendekatan taktik. Pendekatan taktik dalam pembelajaran pendidikan jasmani di sekolah dasar lebih menekankan cara membelajarkan permainan dengan memahami konsep bermain (Yusup et al., 2001, p. 79). Konsep bermain sepak takraw yang diajarkan kepada anak sekolah dasar kelas atas disesuaikan dengan teknik dasar keterampilan sepak takraw. Teknik dasar bermain sepak takraw meliputi sepak sila, sepak kuda, sepak badak, sepak cungkil, heading, memaha, mendada, menapak, sepak mula, smash kedeng, dan blocking (Yusup et al., 2001, pp. 30-42). Teknik-teknik dalam bermain sepak takraw dikelompokkan menjadi beberapa kategori yaitu teknik sepakan, teknik servis, teknik bertahan, dan teknik smash (Ali et al.,, 2003, pp. 22-44)

Untuk memahami permainan sepak takraw di sekolah dasar, yang diajarkan guru 
penjasorkes kepada siswa adalah konsep bermain sepak takraw. Melalui permainan, anak dalam pembelajaran pendidikan jasmani tidak hanya ikut serta dalam kegiatan yang menyenangkan saja, tetapi juga akan terekspos perila$\mathrm{ku}$, filosofis, dan konseptual dalam meningkatkan kompleksitasnya di sekolah (Singleton, 2010, p. 22). Pengembangan model permainan sepak takraw dengan cara modifikasi permainan dimaksudkan agar anak lebih siap secara fisik dan psikis dalam menerima permainan. Pengembangan harus memerhatikan kesempatan dan layanan yang sama bagi setiap anak dalam permainan tersebut. Pengembangan permainan sepak takraw juga harus memerhatikan keterampilan dasar dominan yang dipandang dapat mendukung pencapaian keberhasilan dalam memainkan teknik-teknik dasar sepak takraw. Keterampilan dasar dominan dalam bermain antara lain keterampilan lokomotor, keterampilan nonlokomotor, dan keterampilan manipulatif.

Pengembangan permainan sepak takraw harus memerhatikan prinsip penyesuaian dalam modifikasi permainan. Prinsip ini sering disebut dengan body scaling dengan catatan bahwa aspek fisik (tinggi tubuh dan ukuran anggota badan) dan kemampuan siswa merupakan rujukan untuk menyesuaikan kegiatan (Yusup et al., 2001, p. 48). Implikasi dari asas penyesuaian ini adalah pengembangan modifikasi dari suatu cabang olahraga yang berorientasi pada proses dan dampak pedagogik, bukan kepada hasil akhir. Modifikasi permainan berupa perubahan ukuran, bentuk, dan bahan dari alat yang digunakan, perubahan ukuran lapangan dan tinggi net, serta peraturan permainan yang lebih jelas dan sederhana.

Esensi dari modifikasi permainan sepak takraw adalah untuk memudahkan anak menguasai teknik dasar dan memeroleh pengalaman sukses tanpa ada rasa bosan, jenuh, dan keluhan lelah saat melakukan permainan. Modifikasi permainan diharapkan dapat memberikan kesempatan yang sama bagi semua anak, sehingga permainan tidak hanya dimonopoli oleh anak yang lebih mampu. Berdasarkan uraian di atas, diperlukan pengembangan model permainan sepak takraw sebagai pembelajaran pendidikan jasmani bagi anak sekolah dasar kelas atas.

\section{METODE}

Penelitian ini merupakan penelitian pengembangan. Penelitian pengembangan adalah metode penelitian yang digunakan untuk menghasilkan produk tertentu, dan menguji keefektifan produk tersebut (Sugiyono, 2010, p. 407). Pengembangan dilaksanakan untuk mendapatkan model-model permainan sepak takraw sebagai pembelajaran pendidikan jasmani bagi anak sekolah dasar kelas atas yang disesuaikan dengan tahap-tahap perkembangan dan karakteristik anak.

Uji coba dilakukan dengan tujuan untuk menyempurnakan model permainan dengan memraktikkannya secara langsung di lapangan. Uji coba produk dilakukan sebanyak dua kali yaitu uji coba skala kecil dan uji coba skala besar. Draf model sebelum diujicobakan di lapangan, dimintakan validasi terlebih dahulu kepada ahli materi yang telah ditunjuk. Pada tahap validasi, para ahli materi juga akan memberikan penilaian terhadap draf model yang telah disusun sehingga akan diketahui apakah model yang disusun layak untuk diujicobakan di lapangan. Peran ahli materi dalam tahap uji coba di lapangan adalah sebagai observer untuk mengobservasi kelayakan draf model yang telah disusun dengan kenyataan di lapangan. Setelah proses uji coba lapangan baik skala kecil dan skala besar dilakukan, akan dihasilkan model permainan yang benar-benar valid.

Subjek coba dalam penelitian ini adalah siswa sekolah dasar kelas atas. Sesuai dengan tahapan penelitian, dilaksanakan beberapa tahapan proses pengambilan data. Proses pengambilan data dilakukan dengan uji coba lapangan skala kecil dan skala besar. Uji coba lapangan skala kecil melibatkan siswa dari SDN Minomartani 6 Ngaglik Sleman sebanyak 36 anak. Uji coba lapangan skala besar melibatkan siswa dari SDN Minomartani 1 Ngaglik dan SDN Brengosan 2 Ngaglik Sleman sebanyak 54 anak.

Pelaksanaan penelitian pengembangan ini mengadaptasikan langkah-langkah yang dikembangkan oleh Gall, Gall, dan Borg. Langkahlangkah penelitian pengembangan model Gall, Gall, \& Borg (2007, p. 590) yang harus ditempuh sebagai berikut: (1) analisis kebutuhan untuk mengidentifikasi tujuan, (2) melakukan analisis instruksional, (3) menganalisis peserta didik dan bahan materi, (4) menulis tujuan kinerja, (5) mengembangkan instrumen penilaian produk, (6) mengembangkan strategi instruksional, (7) mengembangkan dan memilih bahan instruksional, (8) desain produk dan melakukan evaluasi formatif terhadap instruksi, (9) merevisi instruksi, dan (10) desain produk dan melakukan evaluasi sumatif. Kesepuluh 


\section{Jurnal Keolahragaan 5 (1), April 2017 - 54}

Mas Setiananda Artyhadewa

langkah tersebut akan menghasilkan produk akhir yang baik dan efektif serta dapat diimplementasikan.

Berdasarkan 10 langkah penelitian dan pengembangan di atas, penelitian ini hanya akan menggunakan 9 langkah, yaitu: (1) menganalisis kebutuhan untuk mengidentifikasi tujuan, (2) melakukan analisis instruksional, (3) menganalisis peserta didik dan bahan materi, (4) menulis tujuan kinerja, (5) mengembangkan instrumen penilaian produk, (6) mengembangkan strategi instruksional, (7) mengembangkan dan memilih bahan instruksional, (8) desain produk dan melakukan evaluasi formatif terhadap instruksi, dan (9) merevisi instruksi. Adapun prosedur yang digunakan sebagai berikut:

\section{Menganalisis Kebutuhan untuk Mengidentifikasi Tujuan}

Berdasarkan studi pendahuluan, terdapat empat permasalahan yang dijadikan sebagai penilaian kebutuhan untuk mengidentifikasi tujuan. Guru penjasorkes lebih sering mengajarkan permainan kasti dan bulu tangkis sebagai pembelajaran permainan bola kecil kepada anak kelas atas. Sekolah belum memiliki sarana dan prasarana untuk bermain sepak takraw. Sekolah yang diobservasi hanya memiliki lapangan olahraga yaitu lapangan sepak bola, lapangan bulu tangkis, lapangan bola voli, dan sepetak tanah lapang yang tidak terlalu luas. Peralatan yang dimiliki sekolah yaitu bola kasti, bola tenis, bola sepak, bola basket, dan bola voli. Guru penjasorkes masih memiliki persepsi bahwa permainan sepak takraw merupakan permainan yang sulit untuk dilakukan dan diajarkan. Referensi buku permainan sepak takraw menjadi kendala bagi pengetahuan guru penjasorkes tentang permainan sepak takraw. Para guru penjasorkes tidak memiliki buku tentang permainan sepak takraw.

Studi pendahuluan dilakukan melalui observasi dan wawancara terhadap guru penjasorkes dan pembelajaran permainan bola kecil di SD Negeri Minomartani 1 Ngaglik, SD Negeri Minomartani 6 Ngaglik, SD Negeri Dayuharjo Ngaglik, dan SD Negeri Brengosan 2 Ngaglik. Peneliti melakukan studi pustaka untuk memelajari konsep dan teknik permainan sepak takraw, hasil penelitian yang relevan, dan teoriteori yang berkaitan dengan pembelajaran pendidikan jasmani bagi anak sekolah dasar kelas atas. Informasi dari hasil observasi dan studi pustaka dianalisis untuk memfokuskan aspek-aspek yang akan menjadi dasar pengem- bangan model permainan sepak takraw bagi anak sekolah dasar kelas atas. Pengembangan difokuskan pada aktivitas permainan yang mengarah kepada gerak dasar permainan atau teknik dasar permainan sepak takraw bagi anak sekolah dasar kelas atas.

\section{Melakukan Analisis Instruksional}

Analisis intruksional yang dilakukan pada penelitian ini adalah mengidentifikasi keterampilan khusus yang dikembangkan dan prosedur pelaksanaan model yang akan diberikan pada anak sekolah dasar kelas atas. Berikut analisis yang telah dilakukan: (1) identifikasi bentuk permainan yang akan digunakan, meliputi aktivitas permainan sepakan, bertahan, servis, smash, dan game yang terdapat pada pengembangan model permainan sepak takraw, (2) identifikasi aspek afektif yang ingin dikembangkan, antara lain menumbuhkan kerja sama, taat, percaya diri, pantang menyerah, komunikasi, tekun, ulet, dan berpartisipasi aktif di setiap permainan, (3) identifikasi aturan keselamatan di sekolah, peraturan permainan, teknik permainan yang digunakan, dan pemilihan bahasa yang komunikatif agar mudah dipahami oleh siswa.

\section{Menganalisis Peserta Didik dan Bahan Materi}

Analisis peserta didik dan bahan materi yang dilakukan sebagai berikut: (1) menganalisis manfaat dan kebutuhan pengembangan model permainan sepak takraw sebagai pembelajaran pendidikan jasmani bagi anak sekolah dasar kelas atas, (2) menganalisis karakteristik pertumbuhan dan perkembangan anak sekolah dasar kelas atas, (3) menentukan indikator pencapaian perkembangan anak dalam melakukan permainan sepak takraw yang dikembangkan.

\section{Menulis Tujuan Kinerja}

Penelitian dan pengembangan ini bertujuan untuk menghasilkan produk berupa pengembangan model permainan sepak takraw sebagai pembelajaran pendidikan jasmani bagi anak sekolah dasar kelas atas yang disusun dalam bentuk buku panduan berjudul "Panduan Bermain Sepak Takraw: Pembelajaran Pendidikan Jasmani bagi Anak Sekolah Dasar Kelas Atas" dan $D V D$ pengembangan model permainan sepak takraw. Sasaran utama pengembangan model permainan sepak takraw adalah anak sekolah dasar kelas atas. Buku panduan disusun untuk memermudah guru penjasorkes sekolah 
dasar memahami pelaksanaan model permainan sepak takraw yang dikembangkan.

\section{Mengembangkan Instrumen Penilaian Produk}

Pengembangan instrumen penilaian produk diawali dengan penyusunan kisi-kisi instrumen. Instrumen penilaian produk akan digunakan untuk menilai draf produk awal, hasil uji coba dengan skala kecil, dan hasil uji coba dengan skala besar. Penilaian pada draf produk awal sebelum uji coba dengan skala kecil bertujuan sebagai validasi produk. Instrumen penilaian produk yang akan dikembangkan terdiri atas dua jenis yaitu kualitatif dan kuantitatif. Instrumen kualitatif adalah lembar saran perbaikan dan catatan lapangan. Instrumen kuantitatif, yaitu: (a) angket skala nilai validasi, (b) penilaian observasi para ahli materi dan guru penjasorkes terhadap model permainan sepak takraw, (c) penilaian observasi para ahli materi dan guru penjasorkes terhadap keefektifan model permainan sepak takraw, (d) penilaian observasi ahli media terhadap rekaman video model permainan sepak takraw, dan (e) kuesioner bagi siswa.

\section{Mengembangkan Strategi Instruksional}

Strategi instruksional yang dimaksud dalam penelitian ini adalah pemilihan strategi untuk memudahkan siswa mencapai tujuan pembelajaran model permainan sepak takraw bagi anak sekolah dasar kelas atas. Pengembangan model permainan sepak takraw disusun menggunakan pendekatan taktik untuk memudahkan anak dalam mencapai gerak dasar yang diinginkan dalam permainan sepak takraw. Setiap model dirancang sesuai dengan gerak dasar atau teknik dasar permainan sepak takraw yang digunakan dalam pembelajaran pendidikan jasmani di sekolah dasar. Materi penyusunan pengembangan model berpedoman pada gerak dasar permainan sepak takraw, kurikulum sekolah dasar kelas atas, dan karakteristik anak sekolah dasar kelas atas.

\section{Mengembangkan dan Memilih Bahan Instruksional}

Bahan instruksional berupa materi, bahasa, dan desain buku "Panduan Bermain Sepak Takraw: Pembelajaran Pendidikan Jasmani bagi Anak Sekolah Dasar Kelas Atas" disusun dalam draf produk awal. Bahasa yang digunakan adalah bahasa Indonesia semibaku. Jenis huruf yang digunakan dalam buku panduan adalah Comic Sans MS agar tidak terkesan kaku dan lebih menarik. Desain gambar pada buku panduan disesuaikan dengan tema setiap pengembangan model permainan sepak takraw. Pemilihan warna menggunakan nuansa warna yang cerah dan ceria.

Model yang disusun dalam draf produk awal dipraktikkan peneliti dalam proses pembelajaran pendidikan jasmani. Proses praktikum didokumentasikan menggunakan handycam. Rekaman video disimpan di dalam digital versatile disc (DVD). Dokumentasi video berfungsi sebagai penyama persepsi validator tentang pengaturan sarana dan prasarana, cara bermain, dan pelaksanaan pengembangan model permainan sepak takraw sebagai pembelajaran pendidikan jasmani bagi anak sekolah dasar kelas atas.

\section{Desain Produk dan Melakukan Evaluasi Formatif terhadap Instruksi}

Evaluasi formatif dilakukan oleh peneliti selama produk dalam masa pengembangan, selain itu berfungsi untuk memberikan masukan peningkatan efektivitas produk (Gall et al., 2007, p. 590). Berikut tahapan evaluasi formatif yang telah dilakukan peneliti.

Pertama proses validasi. Validasi instrumen penelitian pengembangan model permainan sepak takraw sebagai pembelajaran pendidikan jasmani bagi anak sekolah dasar kelas atas menggunakan validasi isi dan expert judgement (validasi ahli). Validasi isi mengacu pada studi pustaka gerak dasar atau teknik dasar permainan sepak takraw, kurikulum sekolah dasar kelas atas, dan konsep pertumbuhan dan perkembangan anak sekolah dasar kelas atas. Validasi ahli dilakukan oleh dua ahli, yaitu: (1) ahli pembelajaran pendidikan jasmani anak sekolah dasar kelas atas, bernama Sukadiyanto, dan (2) ahli permainan sepak takraw, bernama Thamrin. Adapun langkah-langkah validasi sebagai berikut: (1) peneliti menyampaikan draf produk awal, DVD rekaman video praktikkum draf model, dan lembar saran perbaikan kepada ahli materi, (2) ahli materi menyaksikan rekaman video dalam $D V D$ dan menyimak naskah draf model, (3) ahli materi memberikan saran perbaikan secara tertulis di lembar saran perbaikan, (4) peneliti melakukan diskusi dengan validator tentang perbaikan lebih lanjut, (5) peneliti melakukan revisi draf produk awal berdasarkan saran perbaikan dari para ahli, (6) draf yang telah direvisi disampaikan pada ahli materi disertai dengan angket skala nilai validasi. (7) ahli materi melakukan validasi terhadap draf 
produk awal, (8) draf produk awal dinyatakan valid dan dapat dilakukan uji coba lapangan dengan skala kecil apabila sudah mencapai kategori baik.

Kedua uji coba dengan skala kecil. Peneliti berkoordinasi dengan guru penjasorkes sekolah dasar yang akan mengimplementasikan draf pengembangan model permainan sepak takraw. Pelaksanaan uji coba skala kecil bertempat di SD Negeri Minomartani 6 Ngaglik Sleman Yogyakarta dengan menggunakan subjek sebanyak 36 siswa. Dokumentasi dilakukan dengan cara merekam video pelaksanaan uji coba dengan skala kecil. Hasil rekaman video disimpan ke dalam $D V D$ sebagai media observasi para observer yaitu dua ahli materi, satu guru penjasorkes sekolah dasar, dan dua ahli media. Observer guru penjasorkes sekolah dasar pada uji coba skala kecil menggunakan bantuan guru penjasorkes dari sekolah lain yaitu Wahyu Purwo Wiyono. Hal ini dikarenakan peneliti merupakan guru penjasorkes tetap di sekolah tersebut sehingga untuk mengobservasi proses penelitian pada uji coba skala kecil membutuhkan bantuan dari guru penjasorkes lain. Ahli media yang digunakan berjumlah dua orang yaitu Angga Budi Hidayat dari Stylize Photography Purworejo dan Sugeng Saputro dari Infinity Photography Magelang. Observasi dilakukan terhadap substansi pengembangan model permainan sepak takraw dan keefektifan model dalam proses pembelajaran. Observer dalam uji coba skala kecil merupakan para ahli materi yang telah menilai draf produk awal dan ditambah dengan guru penjasorkes sekolah dasar. Hasil penilaian observasi dan saran perbaikan terhadap uji coba skala kecil digunakan peneliti sebagai referensi perbaikan produk yang akan diujicobakan dengan skala besar.

Ketiga uji coba dengan skala besar. Hasil revisi produk diujicobakan dengan skala besar kepada anak sekolah dasar kelas atas dari dua sekolah yaitu SD Negeri Minomartani 1 Ngaglik dan SD Negeri Brengosan 2 Ngaglik Sleman sebanyak 54 anak. Subjek uji coba dengan skala kecil tidak digunakan dalam uji coba skala besar. Pelaksanaan uji coba dengan skala besar direkam untuk diobservasi oleh dua ahli materi, dua guru penjasorkes sekolah dasar, dan dua ahli media. Guru penjasorkes yang mengobservasi yaitu Wahyu Purwo Wiyono dari SDN Brengosan 2 Ngaglik dan Suratiningsih dari SDN Minomartani 1 Ngaglik Sleman. Observasi dilakukan terhadap substansi pengembangan model permainan sepak takraw dan keefektifan model dalam proses pembelajaran. Saran perbaikan dituliskan di lembar observasi yang telah disediakan oleh peneliti. Hasil penilaian dan saran perbaikan akan digunakan sebagai bahan revisi produk akhir.

\section{Merevisi Instruksi}

Hasil penilaian dan saran perbaikan terhadap hasil uji coba dengan skala besar serta catatan lapangan digunakan sebagai materi revisi pengembangan model permainan sepak takraw untuk menyusun produk akhir. Produk akhir yang dihasilkan terdiri atas dua puluh model permainan yang terbagi menjadi lima kategori berdasarkan gerak dasar atau teknik dasar bermain sepak takraw yaitu kategori sepakan, kategori bertahan, kategori servis, kategori smash, dan kategori game. Pengembangan model permainan sepak takraw sebagai pembelajaran pendidikan jasmani bagi anak sekolah dasar kelas atas disusun dalam buku panduan berjudul "Panduan Bermain Sepak Takraw: Pembelajaran Pendidikan Jasmani bagi Anak Sekolah Dasar Kelas Atas" dilengkapi dengan petunjuk teknis pelaksanaan model, aturan keselamatan permainan, dan sarana prasana yang digunakan. Selain buku panduan, pengembangan model permainan sepak takraw juga dikemas ke dalam bentuk $D V D$.

\section{Instrumen Penelitian Data}

\section{Pedoman Umum Wawancara}

Pedoman umum wawancara berisi daftar pertanyaan yang merupakan garis besar tentang hal mendasar yang akan ditanyakan. Pewawancara berhak mengembangkan pertanyaan untuk memerdalam informasi. Pelaksanaan wawancara dilakukan secara terbuka sehingga informan mengetahui bahwa sedang diadakan penelitian dan informan menjadi salah satu sumber informasi. Moleong (2010, p. 187), menyatakan bahwa jenis wawancara terbuka mengharuskan pewawancara membuat kerangka dan garis besar pokok-pokok yang dirumuskan, namun tidak perlu ditanyakan secara berurutan.

\section{Catatan Lapangan}

Catatan lapangan digunakan peneliti untuk mendeskripsikan hasil pengamatan peneliti pada pelaksanaan pembelajaran permainan bola kecil khususnya permainan sepak takraw ketika studi pendahuluan. Catatan lapangan tersebut disertai tanggapan peneliti untuk merefleksikan fenomena di lapangan dengan solusi yang akan digunakan. Instrumen catatan lapangan mem- 
bantu peneliti dalam mengembangkan bentuk model permainan sepak takraw bagi anak sekolah dasar kelas atas.

\section{Angket Skala Nilai}

Angket berisi daftar pernyataan disertai skala nilai digunakan untuk memberikan penilaian pada draf model permainan, observasi pelaksanaan uji coba skala kecil, dan observasi pelaksanaan uji coba skala besar. Angket dalam pelaksanaan uji coba dengan skala kecil dan besar terdiri atas dua macam, yaitu observasi pelaksanaan model dan keefektifan model dalam proses pembelajaran. Dokumentasi pelaksanaan model permainan disimpan dalam $D V D$ sehingga ahli materi, ahli media, dan guru dapat mengobservasi secara berulang-ulang.

\section{Teknik Analisis Data}

Teknik analisis data yang dilakukan dalam penelitian ini yaitu analisis deskriptif kuantitatif dan analisis deskriptif kualitatif. Analisis deskriptif kuantitatif dilakukan untuk menganalisis data-data berikut: (1) data skala nilai hasil penilaian para ahli materi terhadap draf model permainan sepak takraw sebelum pelaksanaan uji coba di lapangan, (2) data hasil observasi para ahli materi dan guru penjasorkes terhadap model permainan sepak takraw, (3) data hasil observasi para ahli materi dan guru penjasorkes terhadap keefektifan model permainan sepak takraw, dan (4) data hasil observasi ahli media terhadap rekaman video model permainan sepak takraw. Sementara analisis deskriptif kualitatif dilakukan terhadap: (1) hasil wawancara dengan guru penjasorkes, (2) data kekurangan model permainan sepak takraw dari ahli materi, ahli media, dan guru penjasorkes, dan (3) data masukan ahli materi, ahli media, dan guru penjasorkes terhadap pengembangan model permainan sepak takraw.

Draf awal permainan sepak takraw dianggap layak untuk diujicobakan dalam skala kecil apabila para ahli telah memberikan validasi dan menyatakan bahwa semua item klasifikasi dalam skala nilai dinilai "ya" dengan cara memberikan tanda centang $(\sqrt{ })$ pada kolom ya. Dalam hal ini terdapat dua jenis nilai, yaitu hasil penilaian "ya" mendapat nilai (1) dan hasil penilaian "tidak" mendapat nilai nol (0). Jika terdapat ahli materi yang berpendapat bahwa item klasifikasi tidak (nilai nol), dilakukan pengkajian ulang terhadap model permainan yang dapat ditindaklanjuti dengan proses revisi.
Untuk data hasil observasi para ahli materi, ahli media, dan guru penjasorkes terhadap model permainan, hasil observasi "ya" mendapat nilai satu (1) dan hasil observasi "tidak" mendapat nilai nol (0). Data hasil observasi keefektifan para ahli materi dan guru penjasorkes terhadap model permainan sepak takraw menggunakan skala nilai. Rentangan penilaian mulai "Tidak Efektif" sampai dengan "Sangat Efektif". Adapun rentangan skor pada lembar observasi keefektifan para ahli materi dan guru penjasorkes terhadap model permainan sepak takraw yaitu: (1) skor 1 untuk penilaian tidak efektif, (2) skor 2 untuk penilaian kurang efektif, (3) skor 3 untuk penilaian efektif, dan (4) skor 4 untuk penilain sangat efektif. Hasil penilaian terhadap item-item observasi dijumlahkan, lalu total nilainya dikonversikan untuk mengetahui kategorinya.

Model yang disusun dianggap layak untuk diujicobakan dengan skala kecil maupun skala besar secara kuantitatif dihitung skor mencapai standar minimal kelayakan. Norma kategorisasi yang akan digunakan sesuai dengan ketentuan Azwar (2003, p. 109) sebagai berikut:

Tabel 1. Pedoman Konversi Nilai

\begin{tabular}{c|c}
\hline Formula & Kategori \\
\hline$X<(\mu-1,0 \sigma)$ & Kurang/Kurang Efektif \\
$(\mu-1,0 \sigma) \leq X<(\mu+1,0 \sigma)$ & Cukup/Cukup Efektif \\
$(\mu+1,0 \sigma) \leq X$ & Baik/Efektif \\
\hline
\end{tabular}

\section{Keterangan:}

$\mathrm{X}=$ jumlah skor subjek

$\mu \quad=$ mean ideal

$=$ jumlah item $\mathrm{x}$

$\left(\frac{\text { skor terting gi }+ \text { skor terendah }}{2}\right)$

$\sigma=$ standar devisiasi ideal

$=1 / 6[$ (jumlah aitem $\mathrm{x}$ skor tertinggi $)-$

(jumlah item x skor terendah)]

Teknik analisis data kualitatif dalam penelitian ini dilakukan bersamaan dengan pengumpulan data. Proses analisis data dilakukan dengan mereduksi data yaitu proses penyelesaian, penyederhanaan, pemfokusan, pengabstraksian, dan pentransformasian data (Arikunto, 2010, p. 29). Reduksi data dilakukan secara berkesinambungan mulai awal pengumpulan data sampai selesai. Setelah melakukan reduksi data, aktivitas analisis data selanjutnya adalah penyajian data dan membuat kesimpulan data. Data kualitatif pada studi pendahuluan berupa hasil wawancara dan catatan lapangan direduksi, disajikan untuk diberi makna, dan terakhir disimpulkan untuk memerjelas masalah yang ada. Hal tersebut dilakukan untuk memerkuat 
latar belakang masalah penelitian. Pada proses pengembangan produk, data berupa saran perbaikan dari pendapat observer direduksi, disajikan, kemudian dianalisis untuk diambil kesimpulan sebagai bahan revisi.

\section{HASIL}

\section{Data Validasi Draf Produk Awal}

Penilaian skala nilai terhadap revisi draf awal model permainan sepak takraw sebelum diujicobakan di lapangan divalidasikan kepada para ahli materi yaitu: (1) ahli permainan sepak takraw dan (2) ahli pembelajaran pendidikan jasmani. Para ahli berpendapat bahwa pengembangan model permainan sepak takraw sebagai pembelajaran pendidikan jasmani bagi anak sekolah dasar yang terdiri atas 20 jenis permainan yang dikelompokkan menjadi 5 kategori berdasarkan teknik dasar bermain yaitu teknik sepakan, bertahan, servis, smash, dan game telah memenuhi persyaratan kelayakan untuk diujicobakan di lapangan. Penghitungan ini menjadi dasar bahwa draf awal model permainan sepak takraw sebagai pembelajaran pendidikan jasmani bagi anak sekolah dasar kelas atas adalah layak untuk dilakukan uji coba skala kecil.

\section{Data Uji Coba dengan Skala Kecil}

Uji coba skala kecil dilakukan pada anak kelas atas SD Negeri Minomartani 6 Ngaglik dengan jumlah 36 anak. Pelaksanaan uji coba skala kecil direkam dalam $D V D$ kemudian diobservasi oleh observer (ahli olahraga sepak takraw, ahli pembelajaran pendidikan jasmani, guru penjasorkes sekolah dasar, dan ahli media). Data yang diperoleh dari observer berupa: (1) data hasil observasi pelaksanaan model permainan sepak takraw, (2) data hasil observasi keefektifan model permainan sepak takraw, dan (3) saran perbaikan. Data uji coba dengan skala kecil model permainan sepak takraw terdiri atas 20 jenis permainan yang dikategorikan menjadi lima (5) kategori berdasarkan teknik dasar bermain yaitu teknik sepakan, bertahan, servis, smash, dan game. Hasil penilaian observasi ahli materi pada uji coba skala kecil terhadap pengembangan model permainan sepak takraw disajikan sebagai berikut.

\section{Hasil Penilaian Observasi Para Ahli Materi}

Penilaian observasi dilakukan para ahli materi pada uji coba skala kecil terhadap pengembangan model permainan sepak takraw yang terdiri atas 20 jenis permainan yang dikate- gorikan menjadi 5 kategori berdasarkan teknik dasar bermain yaitu teknik sepakan, bertahan, servis, smash, dan game. Total nilai para ahli materi untuk 20 permainan semua sama yaitu sebesar 15 terletak pada interval $10 \leq \mathrm{X}$. Jadi, penilaian observasi para ahli materi pada uji coba skala kecil terhadap pengembangan model permainan sepak takraw sebagai pembelajaran pendidikan jasmani bagi anak sekolah dasar kelas atas berkategori baik.

Hasil Penilaian Observasi Keefektifan Para Ahli Materi

Penilaian observasi keefektifan dilakukan para ahli materi pada uji coba skala kecil terhadap pengembangan model permainan sepak takraw yang terdiri atas 20 jenis permainan yang dikategorikan menjadi 5 kategori berdasarkan teknik dasar bermain yaitu teknik sepakan, bertahan, servis, smash, dan game. Total nilai para ahli materi untuk 20 permainan adalah terletak pada interval $30 \leq \mathrm{X}$. Jadi, penilaian observasi para ahli materi pada uji coba skala kecil terhadap pengembangan model permainan sepak takraw sebagai pembelajaran pendidikan jasmani bagi anak sekolah dasar kelas atas berkategori efektif.

\section{Hasil Penilaian Observasi Ahli Media}

Penilaian observasi dilakukan oleh dua ahli media pada uji coba skala kecil terhadap pengembangan model permainan sepak takraw yang terdiri atas 20 jenis permainan yang dikategorikan menjadi 5 kategori berdasarkan teknik dasar bermain yaitu teknik sepakan, bertahan, servis, smash, dan game. Total nilai para ahli media untuk 20 permainan semua sama yaitu sebesar 8 terletak pada interval 5,33 $\leq \mathrm{X}$. Jadi, penilaian observasi ahli media pada uji coba skala kecil terhadap pengembangan model permainan sepak takraw berdasarkan teknik sepakan sebagai pembelajaran pendidikan jasmani bagi anak sekolah dasar kelas atas berkategori baik.

\section{Data Kuesioner Siswa}

Hasil kuesioner bagi siswa terhadap pengembangan model permainan sepak takraw yang terdiri atas 20 jenis permainan yang dikategorikan menjadi 5 kategori berdasarkan teknik dasar bermain yaitu teknik sepakan, bertahan, servis, smash, dan game, menunjukkan bahwa respons dari anak yang menjadi sampel pada uji coba skala kecil, secara umum memberikan respons yang positif terhadap 
seluruh pengembangan model permainan sepak takraw sebagai pembelajaran pendidikan jasmani bagi anak sekolah dasar kelas atas.

\section{Data Masukan Ahli Materi}

Adapun masukan dari para ahli terhadap pengembangan model permainan sepak takraw sebagai berikut: (1) ahli olahraga sepak takraw, memberikan masukan terhadap hasil skala kecil yaitu bahwa peran guru lebih optimal dan interaktif dengan siswa dalam pembelajaran. Peran guru dalam permainan harus berperan penting secara optimal dan interaktif. Peran tersebut dapat membantu anak dalam belajar gerak karena mendapat motivasi, semangat, dan contoh dari guru. Anak tidak akan merasa kesulitan dalam memraktikkan permainan, (2) ahli pembelajaran pendidikan jasmani, tidak memberikan masukan terhadap hasil skala kecil dikarenakan proses pembelajaran melalui pengembangan model permainan sepak takraw sudah efektif dilaksanakan, (3) guru penjasorkes, memberi masukan terhadap hasil skala kecil yaitu jarak antar anak agar diperlebar sehingga tidak terkesan semrawut dan tidak saling tabrakan. Pengaturan posisi dan formasi anak dalam pembelajaran penjas sangat perlu dilakukan karena setiap anak diharuskan untuk bergerak. Untuk itu jarak anak atau kelompok diperlebar menyesuaikan dengan jumlah anak yang ada. Keleluasaan anak dalam bergerak tidak terbatasi oleh jarak yang sempit. (4) Ahli media, ahli media pertama memberi masukan terhadap video rekaman pada skala kecil yaitu angel pengambilan gambar kurang maksimal, suara berbeda-beda saat pemotongan gambar, pencahayaan kurang pas, gambar masih ada yang kurang fokus, suara yang masuk diperjelas lagi, pengaturan zoom in zoom out masih terlalu kasar, saat memberikan contoh difokuskan dengan satu grup dahulu, momen yang penting bisa diperjelas dengan slow motion atau diulang lagi atau fast motion untuk momen yang kurang begitu penting. Ahli media yang kedua memberikan masukan yaitu kamera jangan goyang pada waktu pengambilan video karena jika goyang mampu mengurangi kualitas gambar pada video, ada angel untuk menampilkan gerakan dengan tujuan untuk memberikan penekanan pada gerakan yang dilakukan dengan jelas, per-jelas kualitas gambar dan suara supaya kualitas video bagus, perhatikan posisi pengambilan video supaya tampilan tubuh tidak terpotong, dan pada waktu melakukan zoom in dan zoom out dilakukan dengan pelan supaya tampilan gerakan jelas.

\section{Data Uji Coba dengan Skala Besar}

Uji coba skala besar dilaksanakan di dua sekolah yaitu SDN Brengosan 2 Ngaglik dengan jumlah siswa sebanyak 27 anak dan SDN Minomartani 1 dengan jumlah siswa sebanyak 27 anak. Pelaksanaan uji coba skala besar direkam dalam $D V D$ kemudian diobservasi oleh observer (ahli olahraga sepak takraw, ahli pembelajaran pendidikan jasmani, guru penjasorkes sekolah dasar, dan ahli media). Data yang diperoleh dari observer berupa: (1) data hasil observasi pelaksanaan model permainan sepak takraw, (2) data hasil observasi keefektifan model permainan sepak takraw, dan (3) saran perbaikan. Data uji coba dengan skala besar model permainan sepak takraw terdiri atas 20 jenis permainan yang dikategorikan menjadi lima (5) kategori berdasarkan teknik dasar bermain yaitu teknik sepakan, bertahan, servis, smash, dan game. Hasil penilaian observasi ahli materi pada uji coba skala besar terhadap pengembangan model permainan sepak takraw disajikan sebagai berikut.

\section{Hasil Penilaian Observasi Para Ahli Materi}

Penilaian observasi dilakukan para ahli materi pada uji coba skala besar terhadap pengembangan model permainan sepak takraw yang terdiri atas 20 jenis permainan yang dikategorikan menjadi 5 kategori berdasarkan teknik dasar bermain yaitu teknik sepakan, bertahan, servis, smash, dan game. Total nilai para ahli materi untuk 20 permainan semua sama yaitu sebesar 15 terletak pada interval $10 \leq \mathrm{X}$. Jadi, penilaian observasi para ahli materi pada uji coba skala besar terhadap pengembangan model permainan sepak takraw sebagai pembelajaran pendidikan jasmani bagi anak sekolah dasar kelas atas berkategori baik.

\section{Hasil Penilaian Observasi Keefektifan Para Ahli Materi}

Penilaian observasi keefektifan dilakukan para ahli materi pada uji coba skala besar terhadap pengembangan model permainan sepak takraw yang terdiri atas 20 jenis permainan yang dikategorikan menjadi 5 kategori berdasarkan teknik dasar bermain yaitu teknik sepakan, bertahan, servis, smash, dan game. Total nilai para ahli materi untuk 20 permainan adalah terletak pada interval $30 \leq \mathrm{X}$. Jadi, penilaian observasi para ahli materi pada uji coba skala 
besar terhadap pengembangan model permainan sepak takraw sebagai pembelajaran pendidikan jasmani bagi anak sekolah dasar kelas atas berkategori efektif.

\section{Hasil Penilaian Observasi Ahli Media}

Penilaian observasi dilakukan oleh dua ahli media pada uji coba skala besar terhadap pengembangan model permainan sepak takraw yang terdiri atas 20 jenis permainan yang dikategorikan menjadi 5 kategori berdasarkan teknik dasar bermain yaitu teknik sepakan, bertahan, servis, smash, dan game. Total nilai para ahli media untuk 20 permainan semua sama yaitu sebesar 8 terletak pada interval $5,33 \leq \mathrm{X}$. Jadi, penilaian observasi ahli media pada uji coba skala besar terhadap pengembangan model permainan sepak takraw berdasarkan teknik sepakan sebagai pembelajaran pendidikan jasmani bagi anak sekolah dasar kelas atas berkategori baik.

\section{Data Kuesioner Siswa}

Hasil kuesioner bagi siswa terhadap pengembangan model permainan sepak takraw yang terdiri atas 20 jenis permainan yang dikategorikan menjadi lima (5) kategori berdasarkan teknik dasar bermain yaitu teknik sepakan, bertahan, servis, smash, dan game, menunjukkan bahwa respons dari anak yang menjadi sampel pada uji coba skala besar, secara umum memberikan respons yang positif terhadap seluruh pengembangan model permainan sepak takraw sebagai pembelajaran pendidikan jasmani bagi anak sekolah dasar kelas atas.

\section{Data Masukan Ahli Materi}

Para ahli materi menilai tidak ada kekurangan dan masukan dalam pengembangan model permainan sepak takraw pada uji coba skala besar. Penyempurnaan pada uji coba skala besar sangat maksimal berdasarkan banyaknya kekurangan dan masukan-masukan dari uji coba skala kecil. Bentuk kekurangan dan masukan dari para ahli materi benar-benar diterapkan dalam uji coba skala besar sehingga hasil yang diinginkan dari para ahli materi dapat terpenuhi. Para ahli materi setuju dengan model-model permainan sepak takraw yang dibuat pada skala besar sehingga dapat disetujui untuk dijadikan produk final.

Hasil uji coba skala besar hanya mendapatkan masukan dari ahli media terkait dengan tampilan dari video pengembangan model permainan sepak takraw. Masukan dari kedua ahli media yaitu berikan efek gambar atau suara untuk lebih menarik siswa, berikan ending di akhir video dan timeline view untuk satu gambar informasi masih terlalu cepat. Berdasarkan masukan dari kedua ahli media, peneliti menyikapi masukan tersebut dan mengubah tampilan dari video sesuai dengan saran ahli media. Masukan dari ahli media sangat membantu dalam pembuatan produk final video pengembangan model permainan sepak takraw. Peneliti mengubah video pengembangan model permainan sepak takraw untuk disempurnakan kemudian ditunjukkan kepada ahli media. Ahli media melihat hasil revisi video pada skala besar dan tidak ada masukan lagi dari ahli media. Ahli media setuju dengan revisi dari hasil skala besar untuk dijadikan produk final.

\section{Kajian Produk Akhir}

Setelah mendapat penilaian dan masukan dari semua ahli materi, dilakukan proses-proses revisi terhadap draf model pengembangan permainan sepak takraw sebagai pembelajaran pendidikan jasmani bagi anak sekolah dasar kelas atas. Dari hasil penilaian, masukan, dan revisi dihasilkan pengembangan model permainan sepak takraw sebagai pembelajaran pendidikan jasmani bagi anak sekolah dasar kelas atas yang tertuang dalam bentuk buku panduan berjudul "Panduan Bermain Sepak Takraw: Pembelajaran Pendidikan Jasmani bagi Anak Sekolah Dasar Kelas Atas" dan DVD pengembangan model permainan sepak takraw yang layak digunakan.

\section{SIMPULAN DAN SARAN}

\section{Simpulan}

Berdasarkan hasil penelitian yang telah diuraikan pada bagian pembahasan, dapat diambil kesimpulan sebagai berikut. Pertama, pengembangan model permainan sepak takraw sebagai pembelajaran pendidikan jasmani bagi anak sekolah dasar kelas atas sesuai dengan Kurikulum Tingkat Satuan Pendidikan (KTSP). Pengembangan model permainan sepak takraw dilaksanakan pada proses pembelajaran sebagai materi pembelajaran permainan bola kecil. Kesesuaian pengembangan model permainan ditandai dengan tujuan permainan sepak takraw sesuai dengan muatan Kurikulum Tingkat Satuan Pendidikan (KTSP) mata pelajaran penjasorkes kelas 4, 5, dan 6 pada Standar Kompetensi 1. Memraktikkan gerak dasar ke dalam permainan sederhana dan olahraga serta nilai- 
nilai yang terkandung di dalamnya dan Kompetensi Dasar 1.1 Memraktikkan gerak dasar dalam permainan bola kecil sederhana dengan peraturan yang dimodifikasi, serta nilai kerjasama tim, sportivitas, dan kejujuran.

Kedua, pengembangan model permainan sepak takraw sebagai pembelajaran pendidikan jasmani bagi anak sekolah dasar kelas atas sesuai dengan karakteristik pertumbuhan dan perkembangan anak. Pengembangan model permainan sepak takraw dilaksanakan menggunakan konsep bermain. Hal ini sesuai dengan tingkat pertumbuhan dan perkembangan anak usia sekolah dasar kelas atas yang berada pada tahapan bermain (play stage). Anak usia sekolah dasar kelas atas aktif dalam bermain, menyukai tantangan terhadap permainan baru, anak bekerjasama, berinteraksi, dan berkomunikasi dengan anak lain, serta taat pada peraturan permainan yang berlaku.

Ketiga, pengembangan model permainan sepak takraw sebagai pembelajaran pendidikan jasmani bagi anak sekolah dasar kelas atas sesuai dengan dengan gerak dasar permainan sepak takraw. Model permainan sepak takraw yang dikembangkan berdasarkan teknik dasar bermain yaitu sepakan, bertahan, servis, dan smash. Pengembangan model permainan sepak takraw menghasilkan dua puluh jenis permainan sesuai dengan gerak dasar permainan sepak takraw. Model permainan tersebut yaitu: (1) berdasarkan teknik sepakan: permainan bola apung, permainan bola jinak, permainan bola bumerang, permainan bolalik, dan permainan bolan; (2) berdasarkan teknik bertahan: permainan ombak bola, permainan bolarus, permainan bosi, permainan bolabola, dan permainan bona; (3) berdasarkan teknik servis: permainan bontung, permainan bolatong, permainan perang bola, permainan bolvis, dan permainan bovispo; (4) berdasarkan teknik smash: permainan bomes; dan (5) berdasarkan game: permainan mangdul, permainan bolnet, permainan bolnetri, dan permainan bola vokra.

Keempat, peralatan yang digunakan dalam pengembangan model permainan sepak takraw sesuai dengan pelaksanaan pembelajaran penjasorkes di sekolah dasar. Peralatan yang dipakai merupakan hasil modifikasi dari peralatan yang sudah ada di sekolah. Peralatan yang dimodifikasi membutuhkan daya kreativitas dan inovasi. Peralatan yang dipakai antara lain bola plastik kecil, bola plastik besar, bola mainan emoticon, tali rafia/tambang, tali kasur, kardus/ ember/tong, net, dan lapangan.
Kelima, pengembangan model permainan sepak takraw sebagai pembelajaran pendidikan jasmani bagi anak sekolah dasar kelas atas menyenangkan bagi anak yang melakukan. Model permainan sepak takraw yang dikembangkan menggunakan konsep bermain. Tujuan bermain dalam pengembangan model ini adalah anak dapat melakukan permainan dengan rasa senang dan gembira. Hal ini dibuktikan dengan hasil kuesioner untuk siswa pada seluruh uji coba produk terhadap pengembangan model permainan sepak takraw yang memberikan respons yang positif dan rekaman video pelaksanaan uji coba produk.

Keenam, pengembangan model permainan sepak takraw sebagai pembelajaran pendidikan jasmani bagi anak sekolah dasar kelas atas aman bagi keselamatan anak. Setiap model permainan sepak takraw yang dikembangkan memiliki aturan keselamatan. Aturan keselamatan meminimalisasi terjadinya kecelakaan pada pelaksanaan permainan sehingga guru dapat fokus memberikan pembelajaran.

\section{Saran}

Pertama, saran pemanfaatan berdasarkan penelitian pengembangan yaitu agar model permainan sepak takraw yang dikembangkan dapat digunakan guru penjasorkes sekolah dasar sebagai salah satu bentuk pembelajaran permainan bola kecil pada siswa kelas atas. Guru penjasorkes sebagai pengajar dan pendidik harus mau meningkatkan kemauan dan kemampuan kualitas pembelajaran dengan berbagai bentuk/ model pembelajaran yang inovatif, variatif, dan kreatif.

Kedua, diseminasi hasil penelitian ini dapat dilakukan melalui seminar, kelompok kerja guru penjasorkes, pembuatan artikel, ataupun penelitian baik penelitian tindakan kelas dan penelitian eksperimen dengan melibatkan guru penjasorkes sekolah dasar. Diseminasi hasil penelitian dimaksudkan untuk mengetahui efek nyata dari produk pengembangan model permainan sepak takraw.

Ketiga, untuk pengembangan lebih lanjut perlu dilakukan penelitian yang melibatkan subjek coba yang lebih besar dan cakupan lokasi uji coba yang luas, menyeluruh, dan merata. Pengembangan lebih lanjut dapat juga dilakukan dengan penelitian yang serupa hanya yang berbeda sasaran subjek coba diperuntukkan bagi anak sekolah dasar kelas bawah. 


\section{DAFTAR PUSTAKA}

Ali, N., Hanif, S., \& Jamalong, A. (2003). Panduan bermain sepak takraw pemula (usia dini). Jakarta: Depdiknas.

Arikunto, S. (2010). Prosedur penelitian: Suatu pendekatan praktik. Jakarta: Rineka Cipta.

Azwar, S. (2003). Penyusunan skala psikologi. Yogyakarta : Pustaka Pelajar. http://doi.org/2003

BSNP. (2009). Standar kompetensi dan kompetensi dasar sekolah dasar/madrasah ibtidaiyah mata pelajaran pendidikan jasmani olahraga dan kesehatan. Jakarta: Depdiknas.

Gall, M. D., Gall, J. P., \& Borg, W. R. (2007). Educational research: An introduction. Pearson/Allyn \& Bacon.
Lumintuarso, R. (2013). Pembinaan multilateral bagi atlet pemula (Pedoman latihan dasar bagi atlet muda berbakat). Yogyakarta: UNY Pres.

Moleong, L. J. (2010). Metodologi penelitian kualitatif (Ed. Rev.). Bandung: PT Remaja Rosdakarya. http://doi.org/2010

Singleton, E. (2010). More than "Just a Game": History, pedagogy, and games in physical education. Physical \& Health Education Journal, 76(2), 22-27.

Sugiyono. (2010). Metode penelitian pendidikan: Pendekatan kuantitatif, kualitatif, dan $R \& D$. Bandung: Alfabeta.

Yusup, U., Prawirasaputra, H., Sudrajat, \& Usli, L. (2001). Pembelajaran permainan sepak takraw: Pendekatan keterampilan taktis di $S M U$. Bandung: Mitra Pustaka. 